\title{
KEMANFAATAN PROGRAM/KEGIATAN PEMBANGUNAN DI KOTA JAYAPURA
}

\author{
Marsi Adi Purwadi ${ }^{1}$ \\ marsipurwadi@gmail.com
}

\begin{abstract}
In general, the objective of the study is to analyze the impact of development through physical activities undertaken by Jayapura City Government in 2015 against beneficiaries. The method used is an explanatory analysis. Quantitative descriptive statistical research into the form of measures of concentration, frequency distribution, cross tab analysis. Based on the results from the evaluation of programs / activities undertaken by Jayapura City Government in 2015, it can be concluded that: (1) The median financial and bodily realization through the use of local government budgets in 2015 is quite good because the realization of more than 93 percent ; (2) The General Allocation Fund is the largest source of funds used by Jayapura City Government in the implementation of development through bodily activities in 2015; and (3) The mean community assessing the implementation of development through programs / activities undertaken by the Jayapura City Government through DAK, DAU, DAU / DAK, DID and OTSUS Fund has been optimally and felt useful by the community. While only a small percentage of respondents stated that programs / activities undertaken by the local government have not been beneficial to the improvement to the community economy in Jayapura City.
\end{abstract}

Keywords: development evaluation, program / activity benefit

\section{PENDAHULUAN}

Perubahan yang cepat pada kondisi ekonomi, sosial dan politik di dalam dan luar negeri telah menghadapkan pemerintah daerah pada tuntutan perbaikan dan perubahan dalam pengelolaan pemerintahan. Komponen perencanaan, penganggaran, pelaksanaan dan monitoring evaluasi harus saling terkait, berkesinambungan dalam siklus pembangunan yang terarah, yang dijalankan dengan efisien dan efektif. Namun secara luas diketahui bahwa monitoring dan evaluasi merupakan salah satu aspek dalam siklus manajemen pembangunan yang belum diimplimentasikan dengan baik hingga saat ini, baik secara tepat dan berkesinambungan. Karenanya, perubahan dan perbaikan di atas, harus segera dilakukan melalui upaya monitoring dan evaluasi pelaksanaan dan pencapaian rencana pembangunan sektoral.

Upaya percepatan pembangunan ekonomi secara terfokus ini bertujuan agar daerah tidak tertinggal dalam persaingan, baik itu persaingan antara daerah yang melibatkan pembangunan secara ekonomi mapun sosial. Sehingga itu seluruh potensi daerah baik sumber daya alam maupun sumber daya manusia memiliki peran saling

\footnotetext{
${ }^{1}$ Staf Pengajar Jurusan Ilmu Ekonomi FEB UNCEN
} 
mengisi guna mencapai pembangunan ekonomi daerah yang terpadu dan terinegrasi guna mendorong kemandirian ekonomi daerah.

Kesejahteraan rakyat akan dapat tercapai dan terus ditingkatkan secara berkesinambungan oleh masyarakat itu sendiri dengan memanfaatkan potensi sumber daya yang dimilikinya melalui peningkatan produksi setiap orang atau kelompok, yang bermuara pada menciptakan peningkatan pendapatan dan kemandirian masyarakat. Oleh Sebab itu, guna terwujudnya program pengembangan potensi ekonomi daerah yang terintegrasi maka perlu dilakukan suatu pemetaan potensi sumberdaya alam maupun sumberdaya manusia yang dimiliki secara tepat dan benar, sehingga menjadi kekuatan utama dalam pengembangan ekonomi daerah yang terfokus, kuat dan mandiri.

Salah satu kritik terhadap sistem perencanaan dan penganggaran pada masa lampau adalah terlalu menitik beratkan pada dimensi input (Input based), sehingga kelemahan ini kemudian coba dikoreksi dengan pendekatan output based, yang sesuai namanya lebih melihat pada seberapa besar keluaran yang bisa dihasilkan. Koreksi lebih jauh yang dilakukan berupa performance based yang menekankan pada kinerja, dan bukan terbatas hanya pada keluaran (Output), melainkan juga (Outcome) hasil dan dampak (impact). Sehingga jika dikaitkan dengan struktur manajemen pemerintahan, maka evaluasi dapat dilakukan untuk mengukur kinerja pembangunan melalui indikator input, output, outcome atau impact.

Telah diketahui dan dipahami bersama bahwa hasil evaluasi pembangunan yang dilakukan merupakan alat bantu pemerintah dalam menyusun, menetapkan dan mengelola kebijakan. Dalam konteks kedaerahan dokumen perencanaan yaitu, RKPD dan RPJMD dilakukan evaluasi secara komprehensif untuk menelusuri, mengukur, dan menganalisa hasil dan capaian pelaksanaan rencana pembangunan yang telah ditetapkan. Artinya, evaluasi perlu dilakukan atas Kebijakan/Prioritas Pembangunan, Fokus Prioritas, Program Pembangunan, atau Kegiatan Prioritas. Analisisnya mencakup berhasil atau tidaknya pelaksanaan pembangunan yang telah direncanakan tersebut, termasuk pencapaian target dan sasarannya. Dalam kaitan itu, evaluasi juga perlu dilakukan atas isu-isu pembangunan sektoral yang secara dinamik terus bergulir.

Pada dasarnya kegiatan evaluasi pembangunan dilakukan guna mengetahui gambaran suatu program/kegiatan pada suatu waktu tertentu. Sehingga diketahui sejauh mana relevansi antara perencanaan yang dibuat dengan sasaran yang ingin dicapai. Diharapkan evaluasi dapat memberi pembelajaran mengenai hal-hal yang perlu dilakukan di masa yang akan datang. Terkait tujuan pelaksanaan evaluasi terhadap dokumen perencanaan. 
Sumber utama pendapatan daerah Kota Jayapura berasal dari pendapatan transfer dengan rata-rata proporsi mencapai 79,11 persen. Proporsi terbesar dalam pembentukkan pendapatan transfer berasal dari dana perimbangan dengan rata-rata proporsi 83,60 persen pertahun. Proporsi terbesar dalam pembentukkan dana perimbangan ini berasal dari dana alokasi umum yang kontribusinya mencapai rata-rata 63,91 persen pertahun. Jika dilihat, trend dana perimbangan perkembangannya meningkat sepanjang tahun 2012-2016, namun dari proporsinya terhadap total pendapatan daerah cenderung menurun.

Pendapatan asli daerah juga menunjukkan peningkatan yang cukup positif selama kurun waktu 2012-2016, dimana peningkatannya hampir mencapai 4 persen. Demikian juga untuk dengan lain-lain pendapatan yang sah, menunjukkan peningkatan mencapai 2 persen selama kurun waktu 2012-2016. Hal ini menunjukkan bahwa, peran pendapatan transfer selama kurun waktu 2012-2016 cenderung mengalami penurunan.

\section{Gambar 1. Realisasi Pendapatan Daerah Kota Jayapura Tahun 2011-2015}

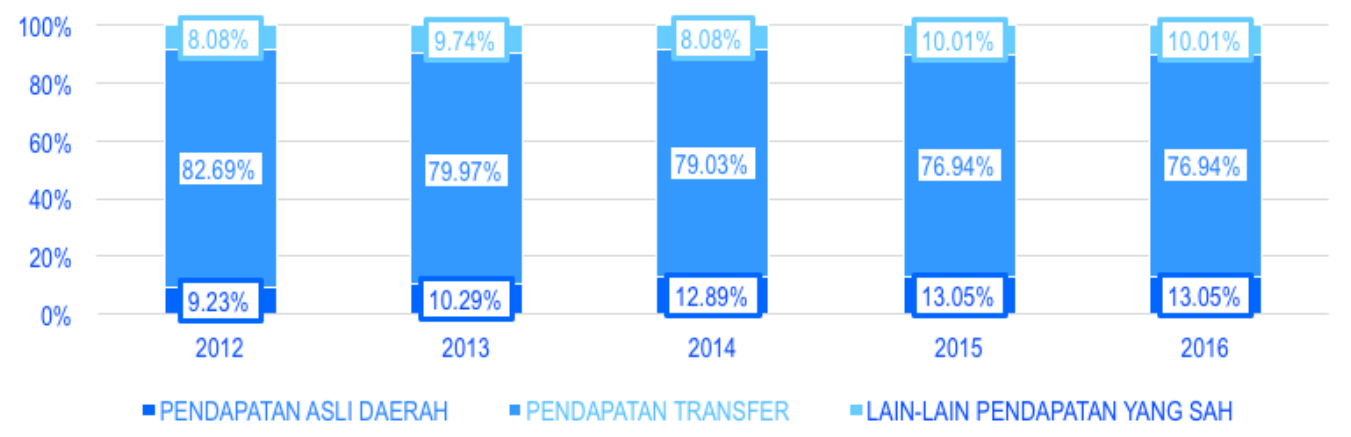

*) data sementara

Sumber: BPKAD Kota Jayapura, 2016

Penerimaan daerah yang diubah menjadi belanja pembangunan yang dilakukan oleh Pemerintah Daerah Kota Jayapura tentunya harus dapat memberikan manfaat pada masyarakat sehingga kegiatan tersebut tidak dianggap kegiatan yang sia-sia dalam upaya meningkatkan kesejahteraan masyarakat. Berdasarkan hasil survey ke masyarakat yang dilakukan oleh BAPPEDA Kota Jayapura tahun 2014, menunjukkan bahwa 74,65\% responden menyatakan bahwa kegiatan-kegiatan yang dilaksanakan telah dirasakan manfaatnya oleh masyarakat, terutama kegiatan-kegiatan yang terkait dengan sosialisasi, diskusi dan seminar. Namun demikian ada juga responden yang menyatakan kegiatankegiatan yang dilaksanakan belum dirasakan manfaatnya, kurang lebih ada $12,91 \%$ yang berpandangan seperti itu, terutama untuk kegiatan-kegiatan 
pembangunan dan pemeliharaan fisik, serta bantuan dan pembinaan. Sedangkan pada tahun 2015 hasil survey ke masyarakat menunjukkan bahwa 56.82\% responden menyatakan bahwa kegiatan- kegiatan yang dilaksanakan telah dirasakan cukup bermanfaat oleh masyarakat. Namun demikian ada juga responden yang menyatakan kegiatan-kegiatan yang dilaksanakan belum dirasakan manfaatnya, kurang lebih ada $3.49 \%$ yang berpandangan seperti itu, terutama untuk kegiatan-kegiatan pembangunan dan pemeliharaan fisik, serta bantuan dan pembinaan.

Pembahasan mengenai program pembangunan yang dilakukan oleh pemerintah tidak dapat dilepaskan dari aspek kebijakan dari pembangunan yang telah ditetapkan sebelumnya. Menurut pandangan Dye (1992), kebijakan atau yang dalam hal ini adalah kebijakan publik secara prinsip dapat diartikan sebagai "Whatever government choose to do or not to do". Pendapat tersebut diperkuat oleh Hogwood dan Gunn (1986) yang menyebutkan bahwa kebijakan publik adalah seperangkat tindakan pemerintah yang didesain untuk mencapai hasil-hasil tertentu. Sedangkan terkait pengertian program itu sendiri, menurut pandangan Jones (1984) adalah cara yang disahkan untuk mencapai tujuan. Sehingga dalam pengertian tersebut dapat digambarkan bahwa program-program adalah penjabaran secara sistematis tentang langkah-langkah dalam mencapai tujuan itu sendiri. Sehingga program pemerintah yang ditetapkan adalah upaya untuk mewujudkan kebijakan-kebijakan pemerintah yang telah ditetapkan.

Menurut pendapat Grigg (1988), infrastruktur merupakan sistem fisik yang menyediakan transportasi, pengairan, drainase, bangunan gedung dan fasilitas publik lainnya, yang dibutuhkan untuk memenuhi kebutuhan dasar manusia baik kebutuhan sosial maupun kebutuhan ekonomi. Pengertian ini merujuk pada infrastruktur sebagai suatu sistem dan dalam sebuah sistem infrastruktur adalah bagian-bagian berupa sarana dan prasarana (jaringan) yang tidak terpisahkan satu sama lain. Kondisi tersebut dikarenakan infrastruktur dalam sebuah sistem menopang sistem sosial dan sistem ekonomi sekaligus menjadi penghubung dengan sistem lingkungan. Dimana ketersediaan infrastruktur memberikan dampak terhadap sistem sosial dan sistem ekonomi yang ada di masyarakat, sehingga infrastruktur perlu dipahami sebagai dasar- dasar dalam mengambil kebijakan (Kodoatie, 2005).

Percepatan pertumbuhan suatu wilayah berkaitan erat dengan pembangunan infrastruktur, yang dalam berbagai pendekatannya dapat menjadi pendorong pertumbuhan wilayah baik secara ekonomi maupun spasial, maupun 
membatasi pertumbuhan suatu wilayah. Salah satu studi yang dilakukan di Amerika Serikat oleh Aschauer pada tahun 1989 dan Munnell pada tahun 1990 menunjukkan bahwa tingkat pengembalian investasi infrastruktur terhadap pertumbuhan ekonomi adalah sebesar 60\% (Dikun,2003).

Oleh sebab itu, Pemerintah Kota Jayapura perlu melakukan suatu evaluasi atas pelaksanaan pembangunan yang telah dilakukan. Dimana tujuan evaluasi yang dilakukan adalah untuk melihat dampak dari program/kegiatan yang dilakukan. BAPPENAS (2009) menggambarkan Evaluasi Dampak sebagai tidakan untuk mengkaji apakah Prioritas, Fokus Prioritas/Program atau Kegiatan Prioritas memberikan pengaruh/manfaat yg telah ditetapkan terhadap penerima manfaat (Perorangan, Rumah Tangga, atau Masyarakat umum).

Secara umum tujuan dari penelitian adalah untuk menganalisa dampak pembangunan yang dilakukan oleh Pemerintah Kota Jayapura pada tahun 2015 terhadap penerima manfaat dalam peningkatan pembangunan di Kota Jayapura, berdasarkan sumber dana pembangunan yang dikelola oleh Pemerintah Kota Jayapura.

\section{METODE PENELITIAN}

\section{Ruang Lingkup}

(1) Lingkup Wilayah. Wilayah kegiatan dari studi ini adalah Kota Jayapura, (2) Lingkup SKPD. Dokumen perencanaan dan penganggaran yang dievaluasi adalah dari seluruh SKPD , (3) Lingkup Obyek. Obyek yang diamati dalam studi ini mencakup indikator-indikator makro dan mikro sosial ekonomi berupa outcome dari hasil pelaksanaan program, dan (4) Lingkup Kegiatan, terdiri atas kegiatan persiapan, pelaksanaan, dan diseminasi.

\section{Populasi dan Sampel}

Populasi dalam penelitian ini adalah jumlah kegiatan fisik yang dilaksanakan oleh Pemerintah Kota Jayapura, dimana pada tahun 2015 jumlah kegiatan fisik adalah sebanyak 82 kegiatan. Dari jumlah kegiatan tersebut kemudian diambil 5 responden untuk menjadi responden pada setiap kegiatan, sehingga jumlah sampel dalam pelaksanaan kegiatan ini adalah sebanyak 406 responden.

\section{Manajemen Data}

(1) Jenis data data sekunder dan primer, (2) Metoda pengumpulan data : survei institiusional, observasi, penyebaran kuesioner, wawancara mendalam, FGD, (3) Metoda sampling : multistage sampling dan purposive sample. 


\section{Metode Analisis}

\section{Analisa Kuantitatif}

STATISTIK DESKRIPTIF KUANTITATIF. Menggunakan statistik deskriptif kuantitatif berupa ukuran-ukuran pemusatan, distribusi frekwensi, crosstab analysis.

SKALA LIKERT. Diterapkan untuk menilai persepsi masyarakat terhadap nilai manfaat kegiatan-kegiatan yang dilaksanakan oleh SKPD, selain juga untuk memonitoring kegiatan SKPD yang telah dilaksanakan.

\section{Analisa Kualitatif}

Metoda yang digunakan adalah analisa deskriptif. Penelitian deskriptif kualitatif menafsirkan dan menuturkan data yang bersangkutan dengan situasi yang sedang terjadi, sikap serta pandangan yang terjadi di dalam masyarakat, pertentangan dua keadaan atau lebih, hubungan antarvariabel, perbedaan antar fakta, pengaruh terhadap suatu kondisi, dan lain-lain.

\section{HASIL ANALISIS DAN PEMBAHASAN}

Realisasi keuangan seluruh SKPD pada tahun 2015 mencapai Rp.422,492,783,953 atau rata-rata sebesar 92,83 persen dan dengan rata-rata realisasi fisik sebesar 98,23 persen. Dimana Dinas Pekerjaan Umum Kota Jayapura adalah SKPD dengan jumlah anggaran tertinggi di Kota Jayapura pada tahun 2015, yaitu senilai Rp.103,526,874,668, dengan presentase realisasi keuangan sebesar fisik sebesar 88.03 persen dan realisasi fisik sebesar 83.46 persen. Namun demikian, SKPD-SKPD dengan jumlah anggaran yang tergolong rendah, hampir seluruhnya memiliki realisasi fisik mencapai 100 persen.

Tabel 1. Jumlah Anggaran dan Realisasi Keuangan/ Fisik Berdasarkan SKPD Kota Jayapura Tahun 2015

\begin{tabular}{|l|r|r|r|r|}
\hline \multicolumn{1}{|c|}{ SKPD } & $\begin{array}{c}\text { Jumlah Anggaran } \\
\text { (Rp) }\end{array}$ & $\begin{array}{c}\text { Realisasi Keuangan } \\
(\mathrm{Rp})\end{array}$ & $\begin{array}{c}\text { Realisasi } \\
\text { Keuangan } \\
(\%)\end{array}$ & $\begin{array}{c}\text { Realisasi } \\
\text { Fisik (\%) }\end{array}$ \\
\hline Satuan Polisi Pamong Praja & $7,650,000,000$ & $7,585,930,000$ & 99.16 & 100.00 \\
\hline $\begin{array}{l}\text { Badan Kepegawaian Daerah Kota } \\
\text { Jayapura }\end{array}$ & $5,900,000,000$ & $5,385,585,100$ & 91.28 & 97.58 \\
\hline $\begin{array}{l}\text { Badan Kesatuan Bangsa, Politik Dan } \\
\text { Linmas }\end{array}$ & $1,700,000,000$ & $1,700,000,000$ & 100.00 & 100.00 \\
\hline Badan Lingkungan Hidup & $5,880,570,000$ & $5,825,109,239$ & 99.06 & 100.00 \\
\hline $\begin{array}{l}\text { Badan Pemberdayaan Masyarakat Dan } \\
\text { Pemerintahan Kampung }\end{array}$ & $11,351,497,485$ & $11,351,497,485$ & 100.00 & 100.00 \\
\hline $\begin{array}{l}\text { Badan Pemberdayaan Perempuan Dan } \\
\text { KB }\end{array}$ & $4,062,730,000$ & $4,062,550,000$ & 100.00 & 100.00 \\
\hline
\end{tabular}


Jurnal Keuda Vol. 2 No. 2

ISSN 2477-7838

\begin{tabular}{|c|c|c|c|c|}
\hline SKPD & $\begin{array}{l}\text { Jumlah Anggaran } \\
\qquad(\mathrm{Rp})\end{array}$ & $\begin{array}{l}\text { Realisasi Keuangan } \\
\qquad(\mathrm{Rp})\end{array}$ & $\begin{array}{l}\text { Realisasi } \\
\text { Keuangan } \\
(\%)\end{array}$ & $\begin{array}{l}\text { Realisasi } \\
\text { Fisik }(\%)\end{array}$ \\
\hline $\begin{array}{l}\text { Badan Penanggulangan Bencana } \\
\text { Daerah }\end{array}$ & $1,850,000,000$ & $1,847,273,000$ & 99.85 & 100.00 \\
\hline $\begin{array}{l}\text { Badan Pendidikan Dan Pelatihan Kota } \\
\text { Jayapura }\end{array}$ & $5,282,000,000$ & $4,841,748,750$ & 91.67 & 100.00 \\
\hline $\begin{array}{l}\text { Badan Pengelola Keuangan Dan Asset } \\
\text { Daerah }\end{array}$ & $35,420,000,000$ & $33,100,952,000$ & 93.45 & 100.00 \\
\hline Badan Pengelola Perbatasan & $3,025,500,000$ & $2,631,123,000$ & 86.96 & 93.80 \\
\hline $\begin{array}{l}\text { Badan Perencanaan Pembangunan } \\
\text { Daerah }\end{array}$ & $10,990,000,000$ & $10,232,212,823$ & 93.10 & 98.78 \\
\hline Badan Perijinan Terpadu Satu Piuntu & $1,830,000,000$ & $1,806,094,600$ & 98.69 & 100.00 \\
\hline $\begin{array}{l}\text { Bagian Administrasi Pemerintahan } \\
\text { Umum Kota Jayapura }\end{array}$ & $6,905,000,000$ & $5,942,092,300$ & 86.05 & 77.84 \\
\hline Bagian Hukum & $1,880,000,000$ & $1,817,565,345$ & 96.68 & 100.00 \\
\hline Bagian Humas Dan Protokoler & $3,000,000,000$ & $2,683,876,120$ & 89.46 & 91.75 \\
\hline $\begin{array}{l}\text { Bagian Layanan Pengadaan Secara } \\
\text { Elektronik }\end{array}$ & $500,000,000$ & $494,385,000$ & 98.88 & 100.00 \\
\hline Bagian Organisasi Dan Tatalaksana & $1,350,000,000$ & $1,293,443,000$ & 95.81 & 100.00 \\
\hline Bagian Umum & $6,350,000,000$ & $5,638,924,980$ & 88.80 & 100.00 \\
\hline Dinas Kebersihan Dan Pemakanan & $13,900,350,000$ & $13,564,289,400$ & 97.58 & 98.64 \\
\hline Dinas Kebudayaan Dan Pariwisata & $4,935,000,000$ & $4,910,480,300$ & 99.50 & 100.00 \\
\hline Dinas Kelautan Dan Perikanan & $11,967,111,364$ & $9,986,056,234$ & 83.45 & 98.50 \\
\hline Dinas Kependudukan Dan Catatan Sipil & $5,000,000,000$ & $4,704,341,515$ & 94.09 & 100.00 \\
\hline Dinas Kesehatan & $28,851,267,650$ & $27,822,279,001$ & 96.43 & 97.58 \\
\hline Dinas Pekerjaan Umum Kota Jayapura & $103,526,874,668$ & $91,130,327,096$ & 88.03 & 83.46 \\
\hline Dinas Pemuda Dan Olahraga & $6,250,000,000$ & $6,078,406,500$ & 97.25 & 100.00 \\
\hline Dinas Pendapatan Daerah & $5,182,270,398$ & $4,618,499,098$ & 89.12 & 91.14 \\
\hline Dinas Pendidikan & $61,412,360,300$ & $57,162,360,300$ & 93.08 & 97.96 \\
\hline Dinas Perhubungan Kotajayapura & $9,671,785,000$ & $6,120,101,200$ & 63.28 & 99.62 \\
\hline $\begin{array}{l}\text { Dinas Perindustrian, Perdagangan Dan } \\
\text { Koperasi }\end{array}$ & $11,394,000,000$ & $11,297,226,555$ & 99.15 & 100.00 \\
\hline Dinas Pertanian Kota Jayapura & $12,395,120,000$ & $12,037,144,802$ & 97.11 & 98.82 \\
\hline Dinas Sosial & $6,139,248,200$ & $6,103,917,250$ & 99.42 & 100.00 \\
\hline Dinas Tata Kota Dan Pertamanan & $8,817,000,000$ & $8,616,023,600$ & 97.72 & 100.00 \\
\hline Dinas Tenaga Kerja & $3,000,000,000$ & $2,993,577,000$ & 99.79 & 100.00 \\
\hline Distrik Abepura & $2,900,000,000$ & $2,900,000,000$ & 100.00 & 100.00 \\
\hline Distrik Heram & $1,650,000,000$ & $1,588,010,000$ & 96.24 & 100.00 \\
\hline Distrik Jayapura Selatan & $2,150,000,000$ & $2,150,000,000$ & 100.00 & 100.00 \\
\hline Distrik Jayapura Utara & $2,650,000,000$ & $2,619,633,000$ & 98.85 & 100.00 \\
\hline Distrik Muara Tami & $1,400,000,000$ & $1,400,000,000$ & 100.00 & 100.00 \\
\hline Inspektorat & $3,400,000,000$ & $2,932,760,200$ & 86.26 & 100.00 \\
\hline $\begin{array}{l}\text { Kantor Ketahanan Pangan Dan } \\
\text { Penyuluhan }\end{array}$ & $1,300,000,000$ & $1,290,430,000$ & 99.26 & 100.00 \\
\hline $\begin{array}{l}\text { Kantor Layanan Pengadaan Barang Dan } \\
\text { Jasa }\end{array}$ & $850,000,000$ & $776,259,160$ & 91.32 & 100.00 \\
\hline $\begin{array}{l}\text { Kantor Perpustakaan, Arsip Dan } \\
\text { Dokumentasi Daerah }\end{array}$ & $1,200,000,000$ & $1,198,124,000$ & 99.84 & 100.00 \\
\hline Sekretariat DPRD & $30,252,175,000$ & $30,252,175,000$ & 100.00 & 100.00 \\
\hline Total & $455,121,860,065$ & $422,492,783,953$ & 92.83 & 98.27 \\
\hline
\end{tabular}

Sumber: RFK Kota Jayapura, Data diolah, 2017 
Pada tahun 2015, terdapat 17 SKPD yang melaksanakan kegiatan fisik, sedangkan SKPD lainnya hanya melaksanakan kegiatan non fisik selama tahun tersebut, Dinas Pekerjaan Umum adalah SKPD dengan jumlah program terbanyak di Kota Jayapura tahun 2015, yaitu sebanyak 11 program dengan jumlah kegiatan fisik sebanyak 21 kegiatan. Jumlah kegiatan fisik yang sama (21 kegiatan) juga dikerjakan oleh Dinas Pendidikan pada tahun 2015. Sedangkan Dinas Tata Kota dan Pemakaman juga melakukan kegiatan dengan jumlah 10 kegiatan dengan 3 program. Jumlah program yang dilakukan pada tahun 2016 adalah sebanyak 38 program dan 82 kegiatan.

Tabel 2. Jumlah Program dan Kegiatan Berdasarkan SKPD di Kota Jayapura Tahun 2015

\begin{tabular}{|l|c|c|}
\hline \multicolumn{1}{|c|}{ SKPD } & PROGRAM & KEGIATAN \\
\hline Badan Lingkungan Hidup & 2 & 4 \\
\hline Badan Pember. Masyarakat Dan Pemerintahan Kampung & 3 & 4 \\
\hline Badan Pemberdayaan Perempuan Dan KB & 1 & 2 \\
\hline Badan Pengelola Keuangan Dan Asset Daerah & 1 & 1 \\
\hline Bagian Administrasi Pemerintahan Umum Kota Jayapura & 1 & 2 \\
\hline Dinas Kebersihan Dan Pemakanan & 1 & 1 \\
\hline Dinas Kesehatan & 3 & 5 \\
\hline Dinas Pekerjaan Umum Kota Jayapura & 11 & 21 \\
\hline Dinas Pemuda Dan Olahraga & 1 & 1 \\
\hline Dinas Pendidikan & 3 & 21 \\
\hline Dinas Perindustrian, Perdagangan Dan Koperasi & 2 & 3 \\
\hline Dinas Pertanian Kota Jayapura & 2 & 2 \\
\hline Dinas Sosial & 1 & 2 \\
\hline Dinas Tata Kota Dan Pertamanan & 3 & 10 \\
\hline Kantor Ketahanan Pangan Dan Penyuluhan & 1 & 1 \\
\hline Kantor Perpustakaan, Arsip Dan Dokumentasi Daerah & 1 & 1 \\
\hline Kantor Satuan Polisi Pamong Praja & 1 & 1 \\
\hline Total & 38 & 82 \\
\hline
\end{tabular}

Sumber: RFK Kota Jayapura, Data diolah, 2017

\section{Karakteristik Responden}

Total responden yang dijadikan sampel dalam kegiatan survei ini berjumlah 406 orang. Mayoritas responden berdomisili di wilayah Distrik Abepura yaitu berjumlah 136 orang atau 33.50 persen, selanjutnya responden di Distrik Jayapura Utara berjumlah 88 orang atau 21.67 persen, Distrik Jayapura Selatan berjumlah 85 orang atau 20.94 persen, Distrik Heram berjumlah 50 orang atau 12.32 persen dan Distrik Muara Tami berjumlah 47 orang atau 11.58 persen dari total responden. 
Tabel 3. Karakteristik Responden Berdasarkan Wilayah Domisili dan Asal Suku

\begin{tabular}{|l|c|c|c|c|c|}
\hline \multirow{2}{*}{ Distrik } & \multicolumn{4}{c|}{ Asal Suku } & \multirow{2}{*}{ Presentase } \\
\cline { 2 - 5 } & N/A & Non Papua & Papua & Jumlah & \\
\hline Abepura & 3 & 82 & 51 & 136 & $33.50 \%$ \\
\hline Heram & & 31 & 19 & 50 & $12.32 \%$ \\
\hline Jayapura Selatan & 2 & 27 & 56 & 85 & $20.94 \%$ \\
\hline Jayapura Utara & & 31 & 57 & 88 & $21.67 \%$ \\
\hline Muara Tami & & 16 & 31 & 47 & $11.58 \%$ \\
\hline Grand Total & 5 & 187 & 214 & 406 & $100.00 \%$ \\
\hline
\end{tabular}

Sumber : Hasil survei, data diolah 2017

Berdasarkan asal suku terlihat bahwa sebagian besar responden merupakan Suku Papua berjumlah 214 orang atau 52.71 persen, dan responden Suku Non Papua berjumlah 187 orang atau 46.06 persen dari total responden, sedangkan responden yang tidak ingin memnyampaikan suku asalnya berjumlah 5 orang atau 1.23 persen dari total responden.

\section{Kemanfaatan Program/Kegiatan (Fisik) Berdasarkan Sumber Dana Pembangunan}

Jumlah realisasi keuangan beberapa kegiatan SKPD yang dijadikan objek penelitian dalam kaitannya dengan pelaksana kegiatan fisik di Kota Jayapura pada tahun 2015 adalah sebesar Rp.105,460,793,578. Dimana pelaksanaan program/kegiatan yang dilakukan, telah dirasakan bermanfaat oleh masyarakat, dengan 92.93 persen responden menyatakan bahwa program/kegiatan yang telah dilakukan oleh Pemerintah Kota Jayapura pada tahun 2015 telah dirasakan optimal karena telah dirasakan bermanfaat, sedangkan hanya sebesar 7.07 persen dari total responden yang menyatakan bawa program/kegiatan yang telah dilakukan oleh Pemerintah Kota Jayapura pada tahun 2015 belum dirasakan optimal, karena belum dirasakan manfaatnya. Beberapa responden yang menilai bahwa program/kegiatan yang dilakukan oleh pemerintah Kota Jayapura belum optimal dirasakan manfaatnya terjadi karena beberapa kegiatan yang dilakukan masih belum dipergunakan sepenuhnya untuk pelayanan kepada masayarakat.

Tabel 4. Persepsi Responden dan Realisasi Keuangan terhadap Kemanfaatan Program/Kegiatan Berdasarkan Sumber Dana Pembangunan di Kota Jayapura Tahun 2015

\begin{tabular}{|c|c|c|c|c|}
\hline \multirow{2}{*}{ Sumber Dana } & \multirow{2}{*}{$\begin{array}{l}\text { Realisasi } \\
\text { Keuangan (Rp.) }\end{array}$} & \multicolumn{3}{|c|}{$\begin{array}{l}\text { Persepsi Masyarakat Terhadap } \\
\text { Kemanfaatan Program/Kegiatan }\end{array}$} \\
\hline & & Optimal & $\begin{array}{l}\text { Belum } \\
\text { Optimal }\end{array}$ & Jumlah \\
\hline Dana Alokasi Khusus (DAK) & $6,580,676,550$ & $79.32 \%$ & $20.68 \%$ & $100 \%$ \\
\hline Dana Alokasi Umum (DAU) & $66,391,565,250$ & $95.08 \%$ & $4.92 \%$ & $100 \%$ \\
\hline
\end{tabular}


Jurnal Keuda Vol. 2 No. 2

ISSN 2477-7838

\begin{tabular}{|l|c|c|c|c|}
\hline \multirow{2}{*}{ Sumber Dana } & \multirow{2}{*}{$\begin{array}{c}\text { Realisasi } \\
\text { Keuangan (Rp.) }\end{array}$} & \multicolumn{3}{|c|}{$\begin{array}{c}\text { Persepsi Masyarakat Terhadap } \\
\text { Kemanfaatan Program/Kegiatan }\end{array}$} \\
\cline { 3 - 5 } & & Optimal & $\begin{array}{c}\text { Belum } \\
\text { Optimal }\end{array}$ & Jumlah \\
\hline Dana Alokasi Umum/Dana Alokasi Khusus (DAU/DAK) & $12,907,093,278$ & $91.90 \%$ & $8.10 \%$ & $100 \%$ \\
\hline Dana Insentif Daerah (DID) & $2,770,000,000$ & $100.00 \%$ & $0.00 \%$ & $100 \%$ \\
\hline Dana Otonom Khusus (OTSUS) & $16,811,458,500$ & $92.06 \%$ & $7.94 \%$ & $100 \%$ \\
\hline Total & $105,460,793,578$ & $92.93 \%$ & $7.07 \%$ & $100 \%$ \\
\hline
\end{tabular}

Sumber: RFK Kota Jayapura, Hasil Survey, Data diolah, 2017

\section{Kemanfaatan Program/Kegiatan yang Bersumber dari Dana Alokasi Khusus (DAK)}

Jumlah realisasi keuangan yang bersumber dari Dana Alokasi Khusus pada beberapa kegiatan SKPD yang dijadikan objek penelitian dalam kaitannya dengan pelaksana kegiatan fisik di Kota Jayapura pada tahun 2015 adalah sebesar Rp.6,580,676,550. Dalam pelaksanaan pembangunan melalui anggaran yang ada, program/kegiatan yang dilakukan telah dirasakan bermanfaat oleh masyarakat. Dimana 81.68 persen responden menyatakan bahwa program/kegiatan yang telah dilakukan oleh Pemerintah Kota Jayapura dengan menggunakan Dana Alokasi Khusus pada tahun 2015 telah dirasakan optimal karena telah bermanfaat, sedangkan hanya sebesar 18.32 persen dari total responden yang menyatakan bawa program/kegiatan yang telah dilakukan oleh Pemerintah Kota Jayapura pada tahun 2015 belum dirasakan optimal, karena belum optimal dirasakan manfaatnya. Beberapa kegiatan yang belum dirasakan optimal dalam memberikan manfaat adalah kegiatan: 1) Pengadaan Alat Kesehatan Puskesmas dan Pustu; 2) Pengadaan Perabotan RKB, Ruang Perpustakaan dan Ruang Kelas SD; dan 3) Pengadaan Sarpas Dalam Rangka Adaptasi Dan Mitigasi. Namun secara keseluruhan, program/kegiatan yang dilakukan dengan menggunakan dana yang bersumber dari Dana Alokasi Khusus telah dirasakan optimal dalam memberikan manfaat bagi pelayanan kepada masyarakat.

Tabel 5. Persepsi Responden dan Realisasi Keuangan terhadap Kemanfaatan Program/Kegiatan yang Bersumber dari Dana Alokasi Khusus di Kota Jayapura Tahun 2015

\begin{tabular}{|c|c|c|c|c|}
\hline \multirow{2}{*}{ Nama Kegiatan } & \multirow{2}{*}{$\begin{array}{c}\text { Realisasi } \\
\text { Keuangan (Rp.) }\end{array}$} & \multicolumn{3}{|c|}{$\begin{array}{l}\text { Persepsi Masyarakat Terhadap } \\
\text { Kemanfaatan Program/Kegiatan }\end{array}$} \\
\hline & & Optimal & $\begin{array}{l}\text { Belum } \\
\text { Optimal }\end{array}$ & Jumlah \\
\hline Pembangunan Kantor Damkar & $2,062,170,000$ & $100.00 \%$ & $0.00 \%$ & $100.00 \%$ \\
\hline $\begin{array}{l}\text { Pengadaan Alat Kesehatan Puskesmas dan Pustu } \\
\text { Kampung }\end{array}$ & 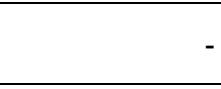 & $60.00 \%$ & $40.00 \%$ & $100.00 \%$ \\
\hline Pengadaan Obat PKD Untuk Puskesmas & $2,970,380,250$ & $100.00 \%$ & $0.00 \%$ & $100.00 \%$ \\
\hline
\end{tabular}




\begin{tabular}{|c|c|c|c|c|}
\hline \multirow{2}{*}{ Nama Kegiatan } & \multirow{3}{*}{$\begin{array}{c}\text { Realisasi } \\
\text { Keuangan (Rp.) }\end{array}$} & \multicolumn{3}{|c|}{$\begin{array}{c}\text { Persepsi Masyarakat Terhadap } \\
\text { Kemanfaatan Program/Kegiatan }\end{array}$} \\
\cline { 3 - 5 } & & Optimal & $\begin{array}{c}\text { Belum } \\
\text { Optimal }\end{array}$ & Jumlah \\
\hline $\begin{array}{l}\text { Pengadaan Perabotan RKB, Ruang Perpustakaan } \\
\text { dan Ruang Kelas SD }\end{array}$ & $331,945,000$ & $50.00 \%$ & $50.00 \%$ & $100.00 \%$ \\
\hline $\begin{array}{l}\text { Pengadaan Sarpas Dalam Rangka Adaptasi dan } \\
\text { Mitigasi }\end{array}$ & $1,216,181,300$ & $98.40 \%$ & $1.60 \%$ & $100.00 \%$ \\
\hline \multicolumn{1}{|c|}{ Grand Total } & $6,580,676,550$ & $81.68 \%$ & $18.32 \%$ & $100.00 \%$ \\
\hline
\end{tabular}

Sumber: RFK Kota Jayapura, Hasil Survey, Data diolah, 2017

\section{Kemanfaatan Program/Kegiatan yang Bersumber dari Dana Alokasi Umum (DAU)}

Realisasi keuangan yang bersumber dari dana Alokasi Umum pada beberapa kegiatan SKPD yang dijadikan objek penelitian dalam kaitannya dengan pelaksana kegiatan fisik di Kota Jayapura pada tahun 2015 adalah sebesar Rp.66,391,565,250. Dalam pelaksanaan pembangunan melalui anggaran yang ada, program/kegiatan yang dilakukan telah dirasakan bermanfaat oleh masyarakat. Dimana 95.74 persen responden menyatakan bahwa program/kegiatan yang telah dilakukan oleh Pemerintah Kota Jayapura dengan menggunakan Dana Alokasi Umum pada tahun 2015 telah dirasakan optimal karena telah bermanfaat, sedangkan hanya sebesar 4.26 persen dari total responden yang menyatakan bawa program/kegiatan yang telah dilakukan oleh Pemerintah Kota Jayapura pada tahun 2015 belum dirasakan optimal, karena belum optimal dirasakan manfaatnya. Terdapat 3 kegiatan dari 35 kegiatan yang belum dirasakan optimal dalam memberikan manfaat, kegiatan tersebut adalah: 1) Pembangunan Kantor Kelurahan Koya Timur, Kelurahan VIM Dan Kelurahan Gurabesi; 2) Pengadaan Pot dan Bunga; dan 3) Rehabilitasi Taman Gramedia. Namun secara keseluruhan, program/kegiatan yang dilakukan dengan menggunakan dana yang bersumber dari Dana Alokasi Umum telah dirasakan optimal dalam memberikan manfaat bagi pelayanan kepada masyarakat Kota Jayapura.

Tabel 6. Persepsi Responden dan Realisasi Keuangan terhadap Kemanfaatan Program/Kegiatan yang Bersuber dari Dana Alokasi Umum di Kota Jayapura Tahun 2015

\begin{tabular}{|l|r|c|c|c|}
\hline \multirow{2}{*}{ Nama Kegiatan } & \multirow{2}{*}{$\begin{array}{c}\text { Realisasi Keuangan } \\
\text { (Rp.) }\end{array}$} & \multicolumn{3}{|c|}{$\begin{array}{c}\text { Persepsi Masyarakat Terhadap } \\
\text { Kemanfaatan Program/Kegiatan }\end{array}$} \\
\cline { 3 - 5 } & & Optimal & $\begin{array}{c}\text { Belum } \\
\text { Optimal }\end{array}$ & Jumlah \\
\hline Normalisasi Kali di Kota Jayapura (Swakelola) & $1,199,997,000$ & $100.00 \%$ & $0.00 \%$ & $100.00 \%$ \\
\hline $\begin{array}{l}\text { Pembangunan Gedung Kantor Distrik Jayapura } \\
\text { Utara (Lanjutan) }\end{array}$ & $930,492,300$ & $100.00 \%$ & $0.00 \%$ & $100.00 \%$ \\
\hline Pembangunan Infrastruktur Jalan Hamadi & $8,256,423,600$ & $100.00 \%$ & $0.00 \%$ & $100.00 \%$ \\
\hline
\end{tabular}


Jurnal Keuda Vol. 2 No. 2

ISSN 2477-7838

\begin{tabular}{|c|c|c|c|c|}
\hline \multirow{2}{*}{ Nama Kegiatan } & \multirow{2}{*}{$\begin{array}{l}\text { Realisasi Keuangan } \\
\quad \text { (Rp.) }\end{array}$} & \multicolumn{3}{|c|}{$\begin{array}{l}\text { Persepsi Masyarakat Terhadap } \\
\text { Kemanfaatan Program/Kegiatan }\end{array}$} \\
\hline & & Optimal & $\begin{array}{l}\text { Belum } \\
\text { Optimal }\end{array}$ & Jumlah \\
\hline Normalisasi Kali di Kota Jayapura (Swakelola) & $1,199,997,000$ & $100.00 \%$ & $0.00 \%$ & $100.00 \%$ \\
\hline \multicolumn{5}{|l|}{ Holtekamp } \\
\hline Pembangunan Jalan & $4,290,736,000$ & $100.00 \%$ & $0.00 \%$ & $100.00 \%$ \\
\hline Pembangunan Jalan Dan Jembatan Pedesaan & $952,904,000$ & $100.00 \%$ & $0.00 \%$ & $100.00 \%$ \\
\hline Pembangunan Jalan di Kota Jayapura & $395,996,000$ & $100.00 \%$ & $0.00 \%$ & $100.00 \%$ \\
\hline $\begin{array}{l}\text { Pembangunan Jalan Sebelum dan Sesudah Kali } \\
\text { Mosso }\end{array}$ & $1,664,611,600$ & $100.00 \%$ & $0.00 \%$ & $100.00 \%$ \\
\hline Pembangunan Jembatan di Kota Jayapura & $1,726,254,000$ & $100.00 \%$ & $0.00 \%$ & $100.00 \%$ \\
\hline Pembangunan Kanopi Trotoar Pusat Kota & $958,596,800$ & $100.00 \%$ & $0.00 \%$ & $100.00 \%$ \\
\hline $\begin{array}{l}\text { Pembangunan Kantor Kelurahan Koya Timur, } \\
\text { Kelurahan VIM Dan Kelurahan Gurabesi }\end{array}$ & $1,316,770,000$ & $50.46 \%$ & $49.54 \%$ & $100.00 \%$ \\
\hline Pembangunan Pasar Entrop (Tahap1) & $697,148,000$ & $100.00 \%$ & $0.00 \%$ & $100.00 \%$ \\
\hline Pembangunan Pasar Youtefa Tahap 1 & $2,211,024,800$ & $100.00 \%$ & $0.00 \%$ & $100.00 \%$ \\
\hline Pembangunan Prasarana Pengaman Pantai & $496,873,200$ & $100.00 \%$ & $0.00 \%$ & $100.00 \%$ \\
\hline Pembangunan Saluran Drainase & $6,909,000,000$ & $100.00 \%$ & $0.00 \%$ & $100.00 \%$ \\
\hline $\begin{array}{l}\text { Pembangunan Sarana dan Prasarana Rumah } \\
\text { Sederhana Sehat }\end{array}$ & $1,316,160,850$ & $100.00 \%$ & $0.00 \%$ & $100.00 \%$ \\
\hline Pembangunan Talud Kodim 1701/Jayapura & $218,211,800$ & $100.00 \%$ & $0.00 \%$ & $100.00 \%$ \\
\hline Pembangunan Taman Lembah Anafree & $1,085,309,000$ & $100.00 \%$ & $0.00 \%$ & $100.00 \%$ \\
\hline Pembangunan Turap/Talud/Beronjong & $2,855,758,200$ & $100.00 \%$ & $0.00 \%$ & $100.00 \%$ \\
\hline Pembersihan Saluran dan Drenase dan Kali & $750,000,000$ & $100.00 \%$ & $0.00 \%$ & $100.00 \%$ \\
\hline Pemeliharaan Listrik Masuk Desa & $991,714,000$ & $100.00 \%$ & $0.00 \%$ & $100.00 \%$ \\
\hline $\begin{array}{l}\text { Pemeliharaan LPJU, LPJU Hias dan Lampu } \\
\text { Salib }\end{array}$ & $879,914,600$ & $100.00 \%$ & $0.00 \%$ & $100.00 \%$ \\
\hline Pemeliharaan Ruang Terbuka Hijau & $349,580,000$ & $100.00 \%$ & $0.00 \%$ & $100.00 \%$ \\
\hline $\begin{array}{l}\text { Pemeliharaan Tugu Pekabaran Injil Di Pulau } \\
\text { Metu Debi }\end{array}$ & $186,207,000$ & $100.00 \%$ & $0.00 \%$ & $100.00 \%$ \\
\hline Penanaman Pohon dan Pemeliharaan & $349,925,000$ & $100.00 \%$ & $0.00 \%$ & $100.00 \%$ \\
\hline Pengadaan Alat Kebersihan Pasar dan K3 & $375,532,500$ & $100.00 \%$ & $0.00 \%$ & $100.00 \%$ \\
\hline Pengadaan Lampu Hias & $\mathrm{N} / \mathrm{A}$ & $100.00 \%$ & $0.00 \%$ & $100.00 \%$ \\
\hline $\begin{array}{l}\text { Pengadaan Pembangkit Listrik Tenaga Surya } \\
\text { Bagi Masyarakat Yang Belum Terlayani Jaringan } \\
\text { PLN }\end{array}$ & $727,883,900$ & $100.00 \%$ & $0.00 \%$ & $100.00 \%$ \\
\hline Pengadaan Pot dan Bunga & $148,289,000$ & $49.82 \%$ & $50.18 \%$ & $100.00 \%$ \\
\hline Pengadaan Sarana Penunjang Karsipan & $250,000,000$ & $100.00 \%$ & $0.00 \%$ & $100.00 \%$ \\
\hline $\begin{array}{l}\text { Pengadaan Tanah Adat dan Negara (Jalan } \\
\text { Masuk Dan Parkir TPU Kristen) }\end{array}$ & $14,942,690,000$ & $100.00 \%$ & $0.00 \%$ & $100.00 \%$ \\
\hline Pengadaan Tiang,Stang dan Pengecetan & $243,575,000$ & $100.00 \%$ & $0.00 \%$ & $100.00 \%$ \\
\hline Peningkatan Jalan Kota & $6,910,553,000$ & $100.00 \%$ & $0.00 \%$ & $100.00 \%$ \\
\hline Rehabilitasi Taman Gramedia & $614,523,600$ & $50.58 \%$ & $49.42 \%$ & $100.00 \%$ \\
\hline Rehabilitasi Taman Lumba-Lumba Dok V & $222,269,000$ & $100.00 \%$ & $0.00 \%$ & $100.00 \%$ \\
\hline Sarana Pendukung Olahraga & $966,641,500$ & $100.00 \%$ & $0.00 \%$ & $100.00 \%$ \\
\hline Grand Total & $66,391,565,250$ & $95.74 \%$ & $4.26 \%$ & $100.00 \%$ \\
\hline
\end{tabular}

Sumber: RFK Kota Jayapura, Hasil Survey, Data diolah, 2017 


\section{Kemanfaatan Program/Kegiatan yang Bersumber dari Dana Alokasi Umum/Dana Alokasi Khusus (DAU/DAK)}

Realisasi keuangan yang bersumber dari DAU/DAK pada beberapa kegiatan SKPD yang dijadikan objek penelitian dalam kaitannya dengan pelaksana kegiatan fisik di Kota Jayapura pada tahun 2015 adalah sebesar Rp.12,907,093,278. Dalam pelaksanaan pembangunan melalui anggaran yang ada, program/kegiatan yang dilakukan telah dirasakan bermanfaat oleh masyarakat. Dimana 93.75 persen responden menyatakan bahwa program/kegiatan yang telah dilakukan oleh Pemerintah Kota Jayapura dengan menggunakan DAU/DAK pada tahun 2015 telah dirasakan optimal karena telah bermanfaat, sedangkan hanya sebesar 6.25 persen dari total responden yang menyatakan bawa program/kegiatan yang telah dilakukan oleh Pemerintah Kota Jayapura pada tahun 2015 belum dirasakan optimal, karena belum optimal dirasakan manfaatnya.

Kegiatan yang masih belum optimal dirasakan manfaatnya adalah kegiatan Pengadaan Alat Peraga, Meubelair, Komputer dan Buku SMP. Hal ini terjadi lebih disebabkan oleh beberapa peralatan yang dieserakan belum dikelola oleh pihak sekolah dengan optimal. Namun secara keseluruhan, program/kegiatan yang dilakukan dengan menggunakan dana yang bersumber dari DAU/DAK telah dirasakan optimal dalam memberikan manfaat bagi pelayanan kepada masyarakat Kota Jayapura.

Tabel 7. Persepsi Responden dan Realisasi Keuangan terhadap Kemanfaatan Program/Kegiatan yang Bersumber dari Dana Alokasi Umum/Dana Alokasi Khusus di Kota Jayapura Tahun 2015

\begin{tabular}{|l|r|c|c|c|}
\hline \multirow{2}{*}{ Nama Kegiatan } & \multicolumn{2}{c|}{$\begin{array}{c}\text { Realisasi } \\
\text { Keuangan (Rp.) }\end{array}$} & \multicolumn{2}{c|}{$\begin{array}{c}\text { Persepsi Masyarakat Terhadap } \\
\text { Kemanfaatan Program/Kegiatan }\end{array}$} \\
\cline { 4 - 5 } & & Optimal & $\begin{array}{c}\text { Belum } \\
\text { Optimal }\end{array}$ & Jumlah \\
\hline $\begin{array}{l}\text { Pembangunan Rumah Dokter, Rumah } \\
\text { Paramedis dan Pagar Pustu }\end{array}$ & $3,155,681,000$ & $100.00 \%$ & $0.00 \%$ & $100.00 \%$ \\
\hline $\begin{array}{l}\text { Pemeliharaan Bangunan Sipil Teknis } \\
\text { Konservasi Tanah Dam Penahan dan Sumur } \\
\text { Resapan }\end{array}$ & $425,940,000$ & $100.00 \%$ & $0.00 \%$ & $100.00 \%$ \\
\hline $\begin{array}{l}\text { Pengadaan Alat Peraga, Meubelair, } \\
\text { Komputer dan Buku SMP }\end{array}$ & $2,233,955,000$ & $50.00 \%$ & $50.00 \%$ & $100.00 \%$ \\
\hline $\begin{array}{l}\text { Pengadaan Sarana dan Prasarana } \\
\text { Pengendalian Pencemaran }\end{array}$ & $4,018,005,878$ & $100.00 \%$ & $0.00 \%$ & $100.00 \%$ \\
\hline Peningkatan Jalan Pedesaan & $1,435,781,400$ & $100.00 \%$ & $0.00 \%$ & $100.00 \%$ \\
\hline $\begin{array}{l}\text { Peningkatan Pengadaan Kelengkapan } \\
\text { Sarana Pelengkapan KB dan KS }\end{array}$ & $1,637,730,000$ & $100.00 \%$ & $0.00 \%$ & $100.00 \%$ \\
\hline $\begin{array}{l}\text { Peningkatan Pengadaan Sarana Pelayanan } \\
\text { KB Dan KS }\end{array}$ & N/A & $100.00 \%$ & $0.00 \%$ & $100.00 \%$ \\
\hline
\end{tabular}


Jurnal Keuda Vol. 2 No. 2

ISSN 2477-7838

\begin{tabular}{|c|r|c|c|c|}
\hline \multirow{2}{*}{ Nama Kegiatan } & \multirow{2}{*}{$\begin{array}{c}\text { Realisasi } \\
\text { Keuangan (Rp.) }\end{array}$} & \multicolumn{3}{|c|}{$\begin{array}{c}\text { Persepsi Masyarakat Terhadap } \\
\text { Kemanfaatan Program/Kegiatan }\end{array}$} \\
\cline { 3 - 5 } & Optimal & $\begin{array}{c}\text { Belum } \\
\text { Optimal }\end{array}$ & Jumlah \\
\hline $\begin{array}{c}\text { Rehabilitasi/Pemeliharaan Jalan Kota } \\
\text { Jayapura (DAK) }\end{array}$ & N/A & $100.00 \%$ & $0.00 \%$ & $100.00 \%$ \\
\hline Grand Total & $12,907,093,278$ & $93.75 \%$ & $6.25 \%$ & $100.00 \%$ \\
\hline
\end{tabular}

Sumber: RFK Kota Jayapura, Hasil Survey, Data diolah, 2017

\section{Kemanfaatan Program/Kegiatan yang Bersumber dari Dana Insentif Daeah (DID)}

Realisasi keuangan yang bersumber dari Dana Insentif Daerah pada beberapa kegiatan SKPD yang dijadikan objek penelitian dalam kaitannya dengan pelaksana kegiatan fisik di Kota Jayapura pada tahun 2015 adalah sebesar Rp.2,770,000,000. Dalam pelaksanaan pembangunan melalui anggaran yang ada, program/kegiatan yang dilakukan telah dirasakan bermanfaat oleh masyarakat. Dimana 100 persen responden menyatakan bahwa program/kegiatan yang telah dilakukan oleh Pemerintah Kota Jayapura dengan menggunakan Dana Insentif Daerah pada tahun 2015 telah dirasakan optimal karena telah bermanfaat. Dengan demikian program/kegiatan yang dilakukan dengan menggunakan dana yang bersumber dari Dana Insentif Daerah telah dirasakan optimal dalam memberikan manfaat bagi pelayanan kepada masyarakat Kota Jayapura.

Tabel 8. Persepsi Responden dan Realisasi Keuangan terhadap Kemanfaatan Program/Kegiatan yang Bersumber dari Dana Insentif Daerah di Kota Jayapura Tahun 2015

\begin{tabular}{|c|c|c|c|c|}
\hline \multirow{2}{*}{ Nama Kegiatan } & \multirow{2}{*}{$\begin{array}{c}\text { Realisasi } \\
\text { Keuangan (Rp.) }\end{array}$} & \multicolumn{3}{|c|}{$\begin{array}{l}\text { Persepsi Masyarakat Terhadap } \\
\text { Kemanfaatan Program/Kegiatan }\end{array}$} \\
\hline & & Optimal & $\begin{array}{l}\text { Belum } \\
\text { Optimal }\end{array}$ & Jumlah \\
\hline Pembangunan Gedung PAUD Skyline & $200,000,000$ & $100.00 \%$ & $0.00 \%$ & $100.00 \%$ \\
\hline $\begin{array}{l}\text { Pembangunan Pagar Keliling SD N Inpres } 1 \\
\text { Koya Timur }\end{array}$ & $474,000,000$ & $100.00 \%$ & $0.00 \%$ & $100.00 \%$ \\
\hline Pembangunan RKB MI Ash Shalihin Abepura & $1,125,000,000$ & $100.00 \%$ & $0.00 \%$ & $100.00 \%$ \\
\hline Pembangunan Talud SMK Negeri 10 Jayapura & N/A & $100.00 \%$ & $0.00 \%$ & $100.00 \%$ \\
\hline Rehab Lantai dan Saluran SD Negeri 3 Jayapura & $175,000,000$ & $100.00 \%$ & $0.00 \%$ & $100.00 \%$ \\
\hline $\begin{array}{l}\text { Rehab Ruang Belajar (Rehab Berat) SMA Negeri } \\
1 \text { Jayapura }\end{array}$ & $550,000,000$ & 10 & $0.00 \%$ & $100.00 \%$ \\
\hline Rehabilitasi SD Negeri Inpres BTN Kotaraja &, 000 & 100.0 & $0.00 \%$ & $100.00 \%$ \\
\hline Grand Total & $2,770,000,000$ & $100.00 \%$ & $0.00 \%$ & $100.00 \%$ \\
\hline
\end{tabular}

Sumber: RFK Kota Jayapura, Hasil Survey, Data diolah, 2017 


\section{Kemanfaatan Program/Kegiatan yang Bersumber dari Dana Otonomi Khusus (OTSUS)}

Berdasarkan hasil realisasi keuangan yang bersumber dari Dana Otonomi Khusus pada beberapa kegiatan SKPD yang dijadikan objek penelitian dalam kaitannya dengan pelaksana kegiatan fisik di Kota Jayapura pada tahun 2015 adalah sebesar Rp.16,811,458,500. Dalam pelaksanaan pembangunan melalui anggaran yang ada, program/kegiatan yang dilakukan telah dirasakan bermanfaat oleh masyarakat. Dimana 94.15 persen responden menyatakan bahwa program/kegiatan yang telah dilakukan oleh Pemerintah Kota Jayapura dengan menggunakan Dana Otonomi Khusus pada tahun 2015 telah dirasakan optimal karena telah bermanfaat, sedangkan hanya sebesar 5.85 persen dari total responden yang menyatakan bawa program/kegiatan yang telah dilakukan oleh Pemerintah Kota Jayapura pada tahun 2015 belum dirasakan optimal, karena belum optimal dirasakan manfaatnya.

Kegiatan yang masih belum optimal dirasakan manfaatnya adalah kegiatan: 1) Meubelir SD Negeri Inpres Perumnas 1 dan SD N Inpres VIM 1, 2) Pembangunan Pagar SMK Negeri 7 Muara Tami, dan 3) Pengadaan Perlengkapan Persalinan Ibu Hamil dan Bayi Balita. Hal ini terjadi lebih disebabkan oleh beberapa peralatan yang dieserakan belum dikelola oleh pihak sekolah dan puskesmas dengan optimal. Namun secara keseluruhan, program/kegiatan yang dilakukan dengan menggunakan dana yang bersumber dari Dana Otonomi Khusus telah dirasakan optimal dalam memberikan manfaat bagi pelayanan kepada masyarakat Kota Jayapura.

Tabel 9. Persepsi Responden dan Realisasi Keuangan terhadap Kemanfaatan Program/Kegiatan yang Bersuber dari Dana Otonomi Khusus di Kota Jayapura Tahun 2015

\begin{tabular}{|l|r|c|c|c|}
\hline \multirow{2}{*}{ Nama Kegiatan } & \multirow{2}{*}{$\begin{array}{c}\text { Realisasi } \\
\text { Keuangan (Rp.) }\end{array}$} & \multicolumn{2}{|c|}{$\begin{array}{c}\text { Persepsi Masyarakat Terhadap } \\
\text { Kemanfaatan Program/Kegiatan }\end{array}$} \\
\cline { 4 - 6 } & & Optimal & $\begin{array}{c}\text { Belum } \\
\text { Optimal }\end{array}$ & Jumlah \\
\hline Bedah Rumah & $996,050,000$ & $100.00 \%$ & $0.00 \%$ & $100.00 \%$ \\
\hline $\begin{array}{l}\text { Meubelir SD Negeri Inpres Perumnas 1 dan SD N } \\
\text { Inpres VIM 1 }\end{array}$ & $250,000,000$ & $60.00 \%$ & $40.00 \%$ & $100.00 \%$ \\
\hline Pembangunan Gedung Guru (PGRI) Jayapura & $200,000,000$ & $100.00 \%$ & $0.00 \%$ & $100.00 \%$ \\
\hline Pembangunan Pagar Dan Gapura & $500,000,000$ & $100.00 \%$ & $0.00 \%$ & $100.00 \%$ \\
\hline Pembangunan Pagar SMK Negeri 7 Muara Tami & $1,500,000,000$ & $53.00 \%$ & $47.00 \%$ & $100.00 \%$ \\
\hline $\begin{array}{l}\text { Pembangunan Pagar SMP Negeri 6 Base G } \\
\text { Jayapura }\end{array}$ & $100,000,000$ & $100.00 \%$ & $0.00 \%$ & $100.00 \%$ \\
\hline Pembangunan Para Para Adat & $350,000,000$ & $100.00 \%$ & $0.00 \%$ & $100.00 \%$ \\
\hline
\end{tabular}


Jurnal Keuda Vol. 2 No. 2

ISSN 2477-7838

\begin{tabular}{|c|c|c|c|c|}
\hline \multirow{2}{*}{ Nama Kegiatan } & \multirow{2}{*}{$\begin{array}{c}\text { Realisasi } \\
\text { Keuangan (Rp.) }\end{array}$} & \multicolumn{3}{|c|}{$\begin{array}{l}\text { Persepsi Masyarakat Terhadap } \\
\text { Kemanfaatan Program/Kegiatan }\end{array}$} \\
\hline & & Optimal & $\begin{array}{l}\text { Belum } \\
\text { Optimal }\end{array}$ & Jumlah \\
\hline Pembangunan Pasar Kampung & $200,000,000$ & $100.00 \%$ & $0.00 \%$ & $100.00 \%$ \\
\hline $\begin{array}{l}\text { Pembangunan RKB dan Ruang Guru SD Tangwala } \\
\text { Skouw Yambe }\end{array}$ & $800,000,000$ & $100.00 \%$ & $0.00 \%$ & $100.00 \%$ \\
\hline $\begin{array}{l}\text { Pembangunan RKB PAUD Sekolah Anak Kecil } \\
\text { Shalom "SAKS" }\end{array}$ & $1,200,000,000$ & $100.00 \%$ & $0.00 \%$ & $100.00 \%$ \\
\hline $\begin{array}{l}\text { Pembangunan Ruang Kelas Baru SD Negeri Koya } \\
\text { Koso/ Satu Atap }\end{array}$ & $669,000,000$ & $100.00 \%$ & $0.00 \%$ & $100.00 \%$ \\
\hline Pembangunan Rumah Ondoafi & $1,000,000,000$ & $100.00 \%$ & $0.00 \%$ & $100.00 \%$ \\
\hline $\begin{array}{l}\text { Pembangunan Rumah Sakit Muara Tami Type C } \\
\text { (Perbatasan) Tahap III }\end{array}$ & $2,817,633,000$ & $100.00 \%$ & $0.00 \%$ & $100.00 \%$ \\
\hline Pembangunan Saluran & $1,192,284,000$ & $100.00 \%$ & $0.00 \%$ & $100.00 \%$ \\
\hline Pemeliharaan Pasar & $1,040,830,000$ & $100.00 \%$ & $0.00 \%$ & $100.00 \%$ \\
\hline $\begin{array}{l}\text { Pengadaan dan Pendistribusian Ternak Bagi } \\
\text { Masyarakat }\end{array}$ & $716,581,000$ & $100.00 \%$ & $0.00 \%$ & $100.00 \%$ \\
\hline $\begin{array}{l}\text { Pengadaan Perlengkapan Persalinan Ibu Hamil dan } \\
\text { Bayi Balita }\end{array}$ & $500,000,000$ & $70.00 \%$ & $30.00 \%$ & $100.00 \%$ \\
\hline Penimbunan SMP Negeri 14 Koya Koso Jayapura & $105,000,000$ & $100.00 \%$ & $0.00 \%$ & $100.00 \%$ \\
\hline Penyediaan Bahan Bangunan Rumah & $1,599,645,700$ & $100.00 \%$ & $0.00 \%$ & $100.00 \%$ \\
\hline $\begin{array}{l}\text { Rehabilitas/Pemeliharaan Jalan dan Jembatan } \\
\text { Pedesaan }\end{array}$ & $1,074,434,800$ & $100.00 \%$ & $0.00 \%$ & $100.00 \%$ \\
\hline Grand Total & $16,811,458,500$ & $94.15 \%$ & $5.85 \%$ & $100.00 \%$ \\
\hline
\end{tabular}

Sumber: RFK Kota Jayapura, Hasil Survey, Data diolah, 2017

\section{KESIMPULAN DAN SARAN}

\section{Kesimpulan}

Berdasarkan hasil evaluasi yang dilakukan terhadap program/kegiatan berdasarkan sumber dana pembangunan yang digunakan oleh Pemerintah Kota Jayapura tahun 2015, maka dapat disimpulkan bahwa:

- Rata-rata realisasi keuangan dan fisik dari penggunaan anggaran pemda pada tahun 2015 tergolong cukup baik karena realisasinya mencapai lebih dari 93 persen.

- Dana Alokasi Umum adalah sumber dana terbesar yang digunakan oleh Pemeintah Kota Jayapura dalam pelaksanaan pembangunan melalui kegiatan-kegiatan fisik di tahun 2015.

- Rata-rata masyarakat menilai pelaksanaan pembangunan melalui program/kegiatan yang dilakukan oleh Pemerintah Kota Jayapura melalui DAK, DAU, DAU/DAK, DID, dan Dana OTSUS telah optimal dan dirasakan bermanfaat oleh masyarakt. Sedangkan hanya sebagian kecil dari responden yang menyatakan bahwa program/kegiatan yang dilaksanakan oleh pemda 
belum bermanfaat untuk peningkatan perekonomian masyarakat di Kota Jayapura.

\section{Kesimpulan}

Berdasarkan respon dan penilaian masyarakat terhadap pelaksanaan program dan kegiatan SKPD tahun 2015. Kegiatan-kegiatan pembangunan fisik yang dilakukan perlu diupayakan untuk:

- Mengoptimalkan pelayanan kesehatan dan pendidikan, dengan memperhatikan mutu, kualitas pelayanan.

- Mendorong peningkatan perekonomian masyarakat, sehingga mampu mengurangi kesenjangan ekonomi saat ini

- Mendorong peningkatan daya saing wilayah, sehingga mampu bersaing dengan wilayah-wilayah lain di Indonesia.

\section{DAFTAR PUSTAKA}

BPS dan Bappeda Kota Jayapura. 2016. Kota Jayapura Dalam Angka Tahun 2016. Badan Pusat Statistik dan Badan Perencanaan dan Pembangunan Daerah Kota Jayapura, Jayapura.

Dikun, Suyono. (2003) Infrastruktur Indonesia : Sebelum, Selama, dan Pasca Krisis. Jakarta: Kementerian Negara PPN/BAPPENAS.

Dye,Thomas R. (1992) Understanding Public Policy. New Jersey: Englewood Cliffs.

Grigg, Neil (1988) Infrastructure Engineering and Management. John Wiley and Sons.

Hewitt, Eleanor \& Michael Bamberger. 1986. Monitoring and Evaluating Urban Development Programs. World Bank, Washington.

Hogwood B.W., Gunn L.A. (1986) Policy Analysis for The Real World. New York: Oxford University Press.

Jones,Charles O. (1984) Pengentar Kebijakan Publik (Public Policy). Jakarta: Rajawali Press

Kedeputian Evaluasi Kinerja Pembangunan Badan Perencanaan Pembangunan Nasional. 2009. Pedoman Evaluasi Kinerja Pembangunan Sektoral. Bappenas RI, Jakarta.

Kodoatie, Robert (2005).Pengantar Manajemen Infrastruktur. Yogyakarta: Pustaka Pelajar 
Peraturan Daerah Kota Jayapura Nomor 4 Tahun 2008 tentang Rencana Pembangunan Jangka Panjang Daerah (RPJPD) Kota Jayapura Tahun 2005-2025. Pemerintah Kota Jayapura, Jayapura.

Peraturan Daerah Kota Jayapura Nomor. Tahun 2012 Tentang Rencana Pembangunan Jangka Menengah Daerah Kota Jayapura Tahun 20122016. Pemerintah Kota Jayapura, Jayapura.

Peraturan Menteri Dalam Negeri Nomor 54 Tahun 2010 Tentang Pelaksanaan Peraturan Pemerintah Nomor 8 Tahun 2008 Tentang Tahapan, Tatacara Penyusunan, Pengendalian, Dan Evaluasi Pelaksanaan Rencana Pembangunan Daerah.

Peraturan Pemerintah Republik Indonesia Nomor 6 Tahun 2008 Tentang Pedoman Evaluasi Penyelenggaraan Pemerintahan Daerah.

Pemerintah Kota Jayapura. 2016. Laporan Realisasi Anggaran Tahun 2012-2015. BPKAD Kota Jayapura, Jayapura. 